

\title{
Pyrrole Azocrown Ethers. Synthesis, Complexation, Selective Lead Transport and Ion-Selective Membrane Electrode Studies
}

Elzbieta Luboch, Ewa Wagner-Wysiecka, Marina Fainerman-Melnikova, Leonard F. Lindoy, Jan F. Biernat

\section{To cite this version:}

Elzbieta Luboch, Ewa Wagner-Wysiecka, Marina Fainerman-Melnikova, Leonard F. Lindoy, Jan F. Biernat. Pyrrole Azocrown Ethers. Synthesis, Complexation, Selective Lead Transport and Ion-Selective Membrane Electrode Studies. Supramolecular Chemistry, 2006, 18 (07), pp.593-601. 10.1080/10610270600879068 . hal-00513483

\section{HAL Id: hal-00513483 \\ https://hal.science/hal-00513483}

Submitted on 1 Sep 2010

HAL is a multi-disciplinary open access archive for the deposit and dissemination of scientific research documents, whether they are published or not. The documents may come from teaching and research institutions in France or abroad, or from public or private research centers.
L'archive ouverte pluridisciplinaire HAL, est destinée au dépôt et à la diffusion de documents scientifiques de niveau recherche, publiés ou non, émanant des établissements d'enseignement et de recherche français ou étrangers, des laboratoires publics ou privés. 


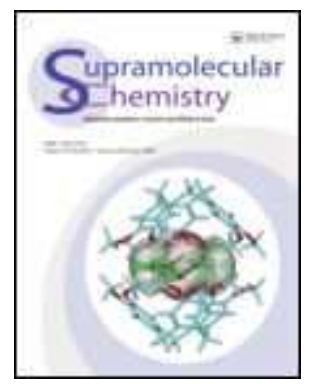

\section{Pyrrole Azocrown Ethers. Synthesis, Complexation, Selective Lead Transport and Ion-Selective Membrane Electrode Studies}

\begin{tabular}{|c|c|}
\hline Journal: & Supramolecular Chemistry \\
\hline Manuscript ID: & GSCH-2006-0010.R1 \\
\hline Manuscript Type: & Full Paper \\
\hline $\begin{array}{r}\text { Date Submitted by the } \\
\text { Author: }\end{array}$ & 18-May-2006 \\
\hline Complete List of Authors: & $\begin{array}{l}\text { Luboch, Elzbieta; Gdansk University of Technology, Department of } \\
\text { Chemical Technology } \\
\text { Wagner-Wysiecka, Ewa; Gdansk University of Technology, Dept. of } \\
\text { Chemical Technology } \\
\text { Fainerman-Melnikova, Marina; University of Sydney } \\
\text { Lindoy, Leonard; University of Sydney } \\
\text { Biernat, Jan; Gdansk University of Technology, Dept. of Chemical } \\
\text { Technology }\end{array}$ \\
\hline Keywords: & $\begin{array}{l}\text { pyrrole macrocycles, azocrown compounds, synthesis, } \\
\text { complexation, lead transport, ion-selective electrodes }\end{array}$ \\
\hline
\end{tabular}

\section{(5cholarONE \\ Manuscript Central}




\title{
Pyrrole Azocrown Ethers. Synthesis, Complexation, Selective Lead
} Transport and Ion-Selective Membrane Electrode Studies

\author{
ELŻBIETA LUBOCH ${ }^{* 1}$, EWA WAGNER-WYSIECKA ${ }^{1}$, MARINA FAINERMAN- \\ MELNIKOVA $^{2}$, LEONARD F. LINDOY ${ }^{2}$, and JAN F. BIERNAT ${ }^{1}$ \\ ${ }^{1}$ Gdansk University of Technology, Department of Chemical Technology, Narutowicza 11-12, 80-952 \\ Gdańsk, Poland; ${ }^{2}$ Centre for Heavy Metals Research, School of Chemistry, University of Sydney, NSW \\ 2006, Australia
}

\begin{abstract}
New 21-membered lipophilic crown ethers, each incorporating a pyrrole unit and two azo groups as macrocyclic ring components, have been synthesized. The complexation behavior of these and two further macrocycles has been investigated in acetonitrile. These ligand systems have been employed as ionophores in transport experiments involving the competitive transport behavior of an equimolar mixture of $\mathrm{Co}^{2+}, \mathrm{Ni}^{2+}, \mathrm{Cu}^{2+}, \mathrm{Zn}^{2+}, \mathrm{Cd}^{2+}, \mathrm{Ag}^{+}$and $\mathrm{Pb}^{2+}$ across a water $(\mathrm{pH}$ 4.9)/chloroform/water (pH 3) bulk membrane system. In each case transport selectivity for lead(II) was obtained. The macrocycles have been incorporated in solvent polymeric membrane electrodes and their behavior towards a selection of metal ions, including those mentioned above, is reported.
\end{abstract}

Abbreviated title: Pyrrole Azocrown Ethers

Keywords: pyrrole macrocycles, azocrown compounds, synthesis, complexation, lead transport, ionselective electrodes

\section{INTRODUCTION}

Polyfunctional molecules that combine dyes and polyether residues to form crown ether analogs represent one category of chromoionophores. Such compounds undergo color

\footnotetext{
* Corresponding author. Tel.: +48 58 3471759. Fax: +48 58 3471949. E-mail: elub@chem.pg.gda.pl
} 
changes on complexation with metal ions and are potentially useful as direct metallochromic reagents or as the sensing elements in integrated optochemical sensors. In previous studies such reagents have mainly incorporated hydroxyazobenzene residues along with polyoxyethylene bridges in their structures [1]. Recently, we have described the synthesis and properties of 18- and 21-membered azomacrocyclic chromoionophores (compounds $\mathbf{1}$ and 2) that contain a pyrrole residue [2]. In these compounds the pyrrole moiety replaces the phenol residue used previously [3,4]. It was found that in acetonitrile the 18-membered pyrrole derivative 1 (Fig. 1, [2]) binds $\mathrm{Ca}^{2+}$, $\mathrm{Sr}^{2+}$ and $\mathrm{Ba}^{2+}$ among the alkaline earth cations to induce a spectral change; in contrast, no spectroscopic responses were obtained for the alkali metal cations or for magnesium. The highest stability was found for the strontium complex $(\log K=3.71$ [2], strontium ionic radius $1.13 \AA$ ). Spectroscopically, 21-membered pyrrole derivative 2 (Fig. 1, [2]) was observed to form complexes only with potassium and barium among the alkali and alkaline earth cations.

It is expected that the presence of a pyrrole residue and two azo units (that are an integral part of a macroring) will increase the susceptibility of a crown system towards the binding of transition/heavy metal cations.

An aim of the present study was to investigate the complexation behavior of the pyrrole azocrown ethers $\mathbf{1} \mathbf{- 4}$ towards selected transition and heavy metal cations as well as to explore their use as ionophores for metal ion transport across bulk liquid membranes. The lipophilicity of the ionophore is an important factor influencing the efficiency of such a transport system. The 21-membered ionophores 3 and 4 (Fig. 1) were synthesized in an attempt to obtain systems of enhanced lipophilicity relative to 2 . Transport of the following cations $\mathrm{Pb}^{2+}, \mathrm{Ag}^{+}, \mathrm{Cu}^{2+}, \mathrm{Cd}^{2+}, \mathrm{Co}^{2+}, \mathrm{Ni}^{2+}$, and $\mathrm{Zn}^{2+}$ was 
studied using bulk membranes doped with macrocycles $\mathbf{1}-\mathbf{4}$. Compounds $\mathbf{1} 5$ were used as ionophores in ion-selective membrane electrodes. These were also employed as ionophores in ion-selective membrane electrodes (ISEs) (compound $\mathbf{5}$ was also subsequently prepared for use in these latter studies when it was observed that its less liphophilic analogue, $\mathbf{2}$ showed a tendency to crystallize in the membrane).
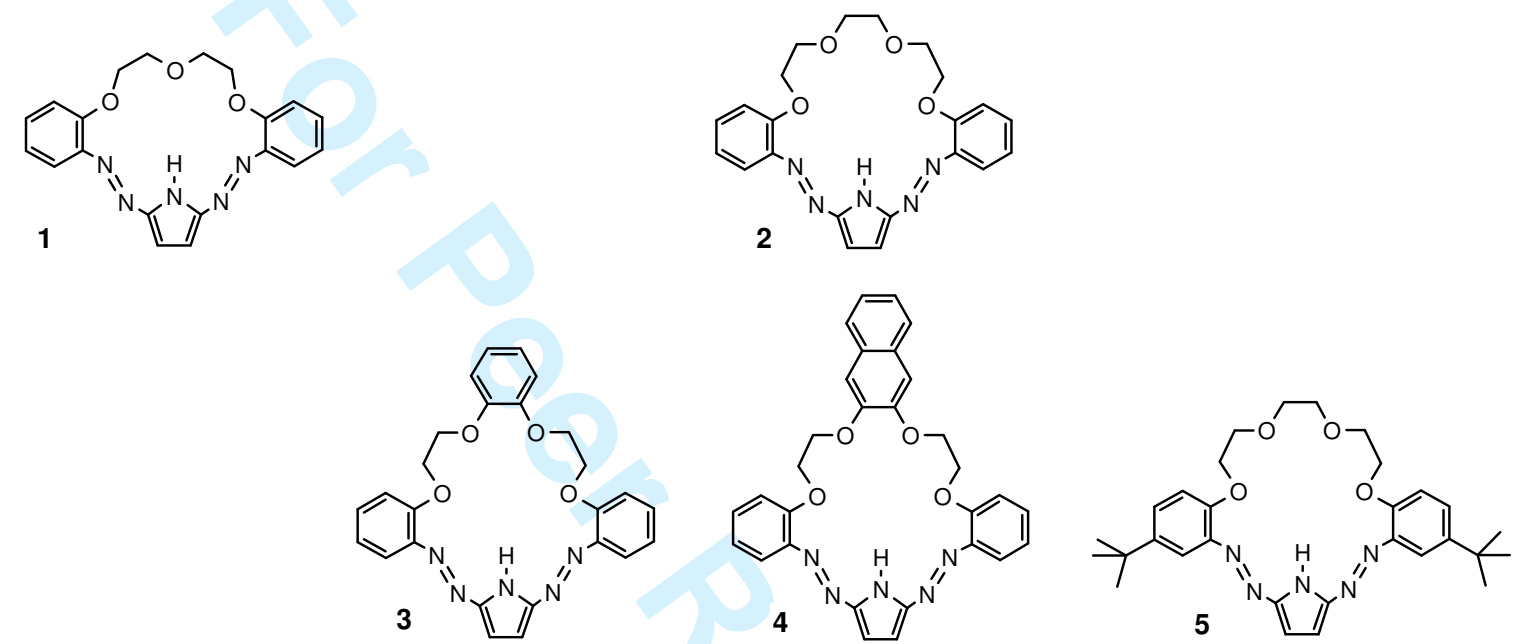

Figure 1 Structures of macrocycles studied.

\section{EXPERIMENTAL}

\section{General}

All materials and solvents used were of analytical reagent grade. Aluminium plates covered with Silica gel $60 \mathrm{~F}_{254}$ (Merck) were used for TLC chromatography. NMR spectra were recorded on a Varian instrument at $500 \mathrm{MHz}$ working frequency. Mass spectra were taken on an AMD-604 spectrometer. UV-Vis spectra were recorded on a Unicam UV-300 spectrophotometer in acetonitrile (HPLC grade). IR spectra were registered using a Genesis II (Mattson) instrument. All aqueous solutions for electrode characterization and for transport experiments were prepared with salts of p.a. purity 
using distilled-deionized water. Atomic absorption spectroscopic measurements were carried on Varian SpectrAA-800 instrument.

\section{Syntheses}

Compounds 1 and $\mathbf{2}$ were obtained as described previously [2]. The syntheses of compounds $\mathbf{3}-\mathbf{5}$ were performed as shown in Scheme 1:

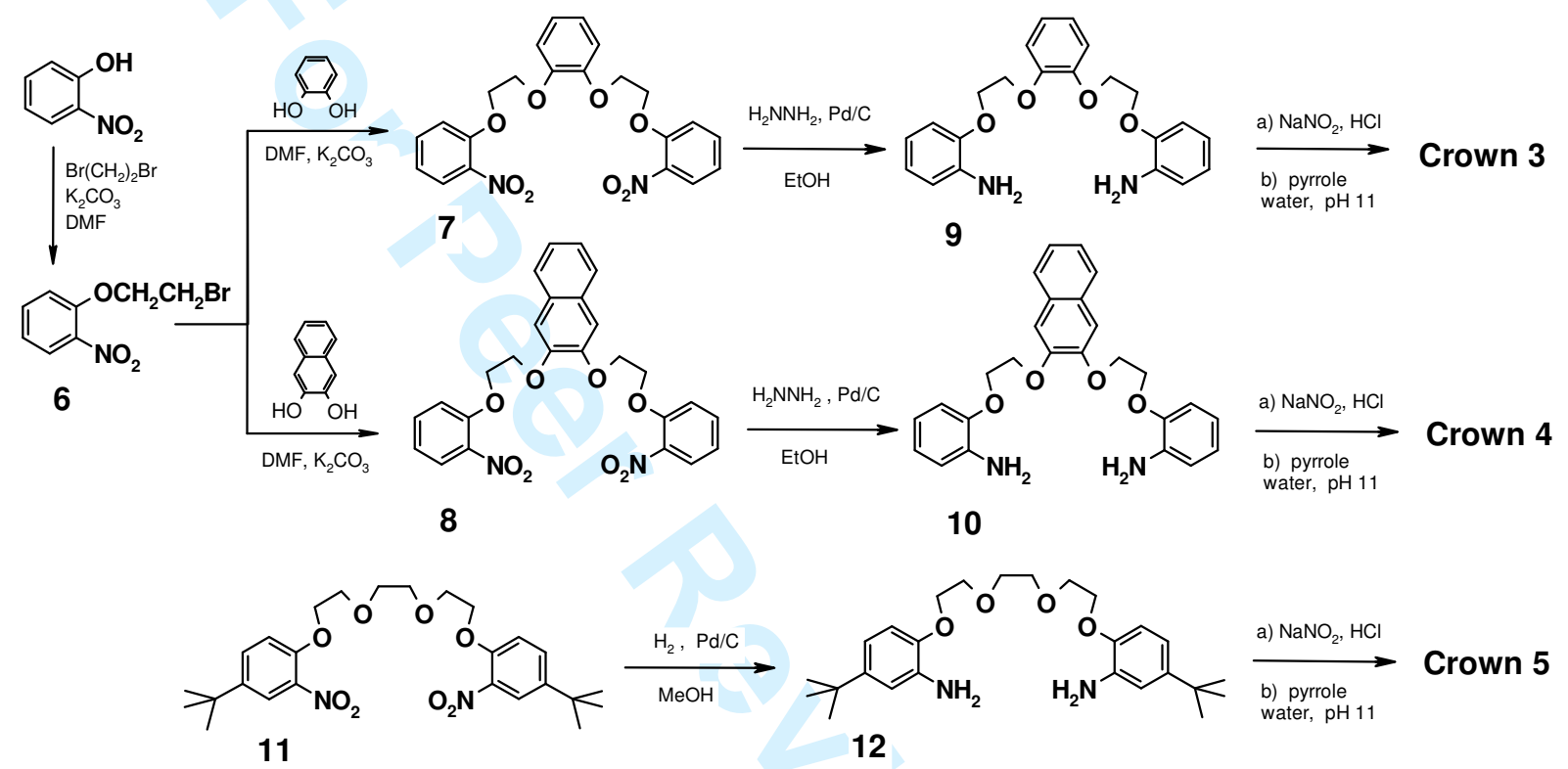

Scheme 1 Synthesis of crowns $\mathbf{3}$ - 5. The final step in each case involved formation of a bis-diazonium intermediate.

1-(2-Bromoethoxy)-2-nitrobenzene 6. A mixture of $o$-nitrophenol (10 g, $72 \mathrm{mmol})$, dibromoethane (40 g, $215 \mathrm{mmol})$ and anhydrous potassium carbonate $(20 \mathrm{~g})$ in dimethylformamide $\left(50 \mathrm{~cm}^{3}\right)$ was stirred and heated at $60^{\circ} \mathrm{C}$ for $4 \mathrm{~h}$. The mixture was diluted with water and the insoluble organic components were dissolved in methylene chloride. The organic phase was evaporated and the residue was dissolved in a hot mixture of methylene chloride and hexane. The small amount of bis(2nitrophenoxy)ethane remaining was filtered off and the filtrate was evaporated. The crude product was purified by column chromatography applying methylene chloride- 
hexane (1:3) mixture as eluent and was finally crystallized from a small amount of hexane at low temperature. Yield $89 \%$, mp 39-40 ${ }^{\circ} \mathrm{C}$. Lit. mp $40^{\circ} \mathrm{C}$ [5]; 36-38 ${ }^{\circ} \mathrm{C}$ [6]. TLC (methylene chloride) $\mathrm{R}_{\mathrm{F}}=0.87 .{ }^{1} \mathrm{H} \mathrm{NMR}\left(\mathrm{CDCl}_{3}\right), \delta[\mathrm{ppm}]: 3.68(2 \mathrm{H}, \mathrm{t}, J=6.4$ $\mathrm{Hz}) ; 4.42(2 \mathrm{H}, \mathrm{t}, J=6.4 \mathrm{~Hz}) ; 7.07-7.12(2 \mathrm{H}, \mathrm{m}) ; 7.54(1 \mathrm{H}, \mathrm{t}, J=7.8 \mathrm{~Hz}) ; 7.84(1 \mathrm{H}$, $\left.\mathrm{dd}, J_{1}=8.3 \mathrm{~Hz}, J_{2}=1.4 \mathrm{~Hz}\right)$.

1,2-Bis[2-(2-nitrophenoxy)ethoxy]benzene 7. A mixture of catechol (0.72 g, $6 \mathrm{mmol})$, $\mathrm{K}_{2} \mathrm{CO}_{3}(3 \mathrm{~g})$, 1-(2-bromoethoxy)-2-nitrobenzene 6 (5 g, $20 \mathrm{mmol}$ ), and dimethylformamide $\left(10 \mathrm{~cm}^{3}\right)$ was stirred at $75^{\circ} \mathrm{C}$ for $24 \mathrm{~h}$. The mixture was diluted with water; the precipitate was collected, washed with water and cold ethanol. The crude product was crystallized from methanol. Yield $94 \%, \mathrm{mp} 126-128^{\circ} \mathrm{C}$ (lit. mp. $128-130^{\circ} \mathrm{C}$ [7]; cf. [8]). TLC: $\mathrm{R}_{\mathrm{F}}=0.55$ (methylene chloride). ${ }^{1} \mathrm{H} \mathrm{NMR}\left(\mathrm{CDCl}_{3}\right), \delta[\mathrm{ppm}]: 4.42-$ $4.56(8 \mathrm{H}, \mathrm{m}) ; 6.98-7.05(6 \mathrm{H}, \mathrm{m}) ; 7.19(2 \mathrm{H}, \mathrm{d}, J=8.3 \mathrm{~Hz}) ; 7.52\left(2 \mathrm{H}, \mathrm{dt}, J_{l}=8.8 \mathrm{~Hz}, J_{2}\right.$ $=1.5 \mathrm{~Hz}) ; 7.81\left(2 \mathrm{H}, \mathrm{dd}, J_{l}=7.8 \mathrm{~Hz}, J_{2}=1.5 \mathrm{~Hz}\right)$.

\section{2,3-Bis[2-(2-nitrophenoxy)ethoxy]naphthalene 8. A mixture of 2,3-}

dihydroxynaphthalene (0.8 g, $5 \mathrm{mmol})$, 1-(2-bromoethoxy)-2-nitrobenzene 6 (2.5 g, 10 $\mathrm{mmol}), \mathrm{K}_{2} \mathrm{CO}_{3}(2 \mathrm{~g})$ and dimethylformamide $\left(8 \mathrm{~cm}^{3}\right)$ was stirred and heated at $90^{\circ} \mathrm{C}$ for $4 \mathrm{~h}$. The mixture was then diluted with water; the precipitate was separated, washed with water and next with methanol. Yield $2.33 \mathrm{~g}(95 \%), \mathrm{mp} 169-170^{\circ} \mathrm{C}$. TLC: $\mathrm{R}_{\mathrm{F}}=0.61$ $\left(\mathrm{CH}_{2} \mathrm{Cl}_{2}\right) .{ }^{1} \mathrm{H}$ NMR (DMSO-d 6$), \delta[\mathrm{ppm}]: 4.42-4.55(8 \mathrm{H}, \mathrm{m}) ; 7.08(2 \mathrm{H}, \mathrm{t}, J=7.8 \mathrm{~Hz})$; $7.31-7.35(2 \mathrm{H}, \mathrm{m}) ; 7.41(2 \mathrm{H}, \mathrm{s}) ; 7.46(2 \mathrm{H}, \mathrm{d}, J=8.3 \mathrm{~Hz}) ; 7.59\left(2 \mathrm{H}, \mathrm{t}, J_{1}=7.8 \mathrm{~Hz}, J_{2}=\right.$ $1.5 \mathrm{~Hz}) ; 7.71-7.75(2 \mathrm{H}, \mathrm{m}) ; 7.82\left(2 \mathrm{H}, \mathrm{dd}, J_{1}=8.3 \mathrm{~Hz}, J_{2}=1.5 \mathrm{~Hz}\right)$. IR (nujol): 1607, 
1520, 1350, 1281, 1251, 1164, 1055, 940, 856, $739 \mathrm{~cm}^{-1}$. HRMS [EI]: Found 490.1371;

$\mathrm{C}_{26} \mathrm{H}_{22} \mathrm{O}_{8} \mathrm{~N}_{2}$ requires 490.1376 .

1,2-Bis[2-(2-aminophenoxy)ethoxy]benzene 9 . To boiling mixture of podand 7 (2.5 g, $5.7 \mathrm{mmol})$, ethanol $\left(60 \mathrm{~cm}^{3}\right)$ and $\mathrm{Pd} / \mathrm{C}$ catalyst, six portions, each of $0.5 \mathrm{~cm}^{3}$ of $98 \%$ hydrazine hydrate was added in $30 \mathrm{~min}$. intervals. Boiling was continued for $4 \mathrm{~h}$ and the reaction progress was monitored by TLC. Finally the catalyst was removed and the diamine was crystallized from ethanol. Yield $56 \%, \mathrm{mp} 109-111^{\circ} \mathrm{C}$. TLC: $\mathrm{R}_{\mathrm{F}}=0.68$ (methylene chloride - acetone 10:1). ${ }^{1} \mathrm{H} \mathrm{NMR}\left(\mathrm{CDCl}_{3}\right), \delta[\mathrm{ppm}]: 3.81(4 \mathrm{H}, \mathrm{bs}) ; 4.34-$ $4.39(8 \mathrm{H}, \mathrm{m}) ; 6.66-6.73(4 \mathrm{H}, \mathrm{m}) ; 6.82-6.88(4 \mathrm{H}, \mathrm{m}) ; 6.96-7.01(4 \mathrm{H}, \mathrm{m})$. IR (nujol): $3477,3445,3379,3362,1613,1505,1222,1128,1056,931,735 \mathrm{~cm}^{-1}$.

\section{2,3-Bis[2-(2-aminophenoxy)ethoxy]naphthalene 10. Hydrazine hydrate $\left(98 \%, 2 \mathrm{~cm}^{3}\right)$} was added portion-wise $\left(0.5 \mathrm{~cm}^{3}\right.$, each portion at $30 \mathrm{~min}$. intervals $)$ to a suspension of nitropodand $8(2.4 \mathrm{~g}, 4 \mathrm{mmol})$ and $\mathrm{Pd} / \mathrm{C}$ catalyst in boiling ethanol $\left(40 \mathrm{~cm}^{3}\right)$. After the reaction was complete (TLC), the hot mixture was filtered and the solid residue was washed with hot ethanol and with chloroform. The combined filtrates were concentrated and allowed to stand whereupon the product crystallized. Yield $1.45 \mathrm{~g}(85 \%)$, mp 165 $166^{\circ} \mathrm{C} . \mathrm{TLC}: \mathrm{R}_{\mathrm{F}}=0.38$ (methylene chloride - acetone $\left.30: 1\right) .{ }^{1} \mathrm{H} \mathrm{NMR}\left(\mathrm{CDCl}_{3}\right), \delta$ [ppm]: $3.88(4 \mathrm{H}, \mathrm{bs}) ; 4.41-4.51(8 \mathrm{H}, \mathrm{m}) ; 6.78-6.80(4 \mathrm{H}, \mathrm{m}) ; 6.82-6.87(2 \mathrm{H}, \mathrm{m})$; $6.89-6.93(2 \mathrm{H}, \mathrm{m}) ; 7.27(2 \mathrm{H}, \mathrm{s}) ; 7.33-7.37(2 \mathrm{H}, \mathrm{m}) ; 7.66-7.70(2 \mathrm{H}, \mathrm{m})$. IR (nujol): $3459,3357,1617,1503,1264,1211,1173,1116,1053,945,864,740 \mathrm{~cm}^{-1}$. 
1,8-Bis(2-amino-4-t-butylphenoxy)-3,6-dioxaoctane 12. The amine was obtained by reduction of 1,8-bis(2-nitro-4-t-butylphenoxy)-3,6-dioxaoctane 11 [9] with hydrogen using $\mathrm{Pd} / \mathrm{C}$ catalyst in methanol. The reaction was carried out for $8 \mathrm{~h}$ at room temp. The product was purified by column chromatography using methylene chloride-acetone (10:1) mixture as eluent. Yield, $88 \%$ of an oily product. TLC: $\mathrm{R}_{\mathrm{F}}=0.19$ (methylene chloride - acetone 10:1). ${ }^{1} \mathrm{H}$ NMR $\left(\mathrm{CDCl}_{3}\right): 1.28(18 \mathrm{H}, \mathrm{s}) ; 3.75(4 \mathrm{H}, \mathrm{s}) ; 3.86(4 \mathrm{H}, \mathrm{t}, J=$ $4.8 \mathrm{~Hz}) ; 3.92(4 \mathrm{H}, \mathrm{bs}) ; 4.15(4 \mathrm{H}, \mathrm{t}, J=4.8 \mathrm{~Hz}) ; 6.70$ - 6.80 (6H, m). IR (film): 3455 , 3363, 2958, 2925, 2897, 1614, 1517, 1455, 1428, 1393, 1362, 1293, 1253, 1142, 1079, $942,865,798 \mathrm{~cm}^{-1}$.

\section{Pyrrole azocrown ether 3.}

Solution A. Conc. hydrochloric acid $\left(1 \mathrm{~cm}^{3}\right)$ was added to a suspension of diamine 9 $(0.76 \mathrm{~g}, 2 \mathrm{mmol})$ in water $\left(40 \mathrm{~cm}^{3}\right)$. An ice-cooled solution of sodium nitrite $(0.28 \mathrm{~g}, 4$ mmol) in water $\left(2 \mathrm{~cm}^{3}\right)$ was added to the above (cooled) suspension of hydrochloride. The mixture was allowed to stand for $15 \mathrm{~min}$ at $5^{\circ} \mathrm{C}$.

Solution B. Pyrrole $\left(0.14 \mathrm{~cm}^{3}, 2 \mathrm{mmol}\right)$ and sodium hydroxide $(0.2 \mathrm{~g})$ were dissolved in a mixture of $40 \mathrm{~cm}^{3}$ water and $2 \mathrm{~cm}^{3}$ ethanol.

Cold solutions $A$ and $B$ were added drop by drop with the same rate over $45 \mathrm{~min}$. to a vigorously stirred water $\left(600 \mathrm{~cm}^{3}\right)$ adjusted to $\mathrm{pH} \sim 11$ with $\mathrm{NaOH}$. Stirring was continued overnight (the $\mathrm{pH}$ was maintained during the initial stages of this coupling procedure). During the first $4 \mathrm{~h}$ the temperature was maintained at $5-10^{\circ} \mathrm{C}$ and was then allowed to rise to $20^{\circ} \mathrm{C}$. The reaction mixture was cooled to $5^{\circ} \mathrm{C}$, adjusted to $\mathrm{pH} \sim 6$ with acetic acid and the precipitate that formed collected. The crude product was purified by column chromatography using methylene chloride initially and then a 
methylene chloride-acetone (30:1) mixture as eluent. Yield 30\%, mp 206-208 ${ }^{\circ} \mathrm{C}$ (crystallized from propan-2-ol). TLC: $\mathrm{R}_{\mathrm{F}}=0.4$ (toluene - ethyl acetate 5:1). ${ }^{1} \mathrm{H}$ NMR (acetone- $\left.\mathrm{d}_{6}\right), \delta[\mathrm{ppm}]: 4.60-4.72(8 \mathrm{H}, \mathrm{m}) ; 6.92-6.96(2 \mathrm{H}, \mathrm{m}) ; 7.07-7.17(6 \mathrm{H}, \mathrm{m})$; $7.42(2 \mathrm{H}, \mathrm{d}, J=8.3 \mathrm{~Hz}) ; 7.49\left(2 \mathrm{H}, \mathrm{dt}, J_{l}=5.1 \mathrm{~Hz}, J_{2}=1.5 \mathrm{~Hz}\right) ; 7.78\left(2 \mathrm{H}, \mathrm{dd}, J_{l}=8.3\right.$ $\left.\mathrm{Hz}, J_{2}=1.5 \mathrm{~Hz}\right) ; 12.30$ (1H, s). IR (nujol): 3437, 1580, 1379, 1237, 1057, 934, $750 \mathrm{~cm}^{-}$ ${ }^{1}$. UV-Vis (acetonitrile): $\lambda_{\max }=500 \mathrm{~nm}, \varepsilon_{\max }=2.3 \times 10^{4}$. HRMS [EI]: Found 469.17465; $\mathrm{C}_{26} \mathrm{H}_{23} \mathrm{~N}_{5} \mathrm{O}_{4}$ requires 469.17500 .

Pyrrole azocrown 4. Crown $\mathbf{4}$ was prepared analogously to $\mathbf{3}$ starting from bisamine $\mathbf{1 0 .}$ The crude product was purified by column chromatography using methylene chlorideacetone (30:1) mixture as eluent. The chromatographic separation was repeated and the product was crystallized from propan-2-ol. Yield $15 \%, \mathrm{mp} 227-229^{\circ} \mathrm{C} . \mathrm{TLC}: \mathrm{R}_{\mathrm{F}}=0.82$ (methylene chloride - acetone 50:1). ${ }^{1} \mathrm{H}$ NMR (acetone- $\left.\mathrm{d}_{6}\right), \delta[\mathrm{ppm}]: 4.70-4.74(4 \mathrm{H}$, m); $4.79-4.82(4 \mathrm{H}, \mathrm{m}) ; 7.08(2 \mathrm{H}, \mathrm{t}, J=7.6 \mathrm{~Hz}) ; 7.16(2 \mathrm{H}, \mathrm{s}) ; 7.30-7.33(2 \mathrm{H}, \mathrm{m})$; $7.37(2 \mathrm{H}, \mathrm{d}, J=8.3 \mathrm{~Hz}) ; 7.47(2 \mathrm{H}, \mathrm{s}) ; 7.47-7.52(2 \mathrm{H}, \mathrm{m}) ; 7.71-7.74(2 \mathrm{H}, \mathrm{m}) ; 7.76$ $\left(2 \mathrm{H}, \mathrm{dd}, J_{1}=7.8 \mathrm{~Hz}, J_{2}=1.6 \mathrm{~Hz}\right) ; 12.36(1 \mathrm{H}, \mathrm{bs})$. IR (nujol): 3610, 1590, 1260, 1122 , 950, $742 \mathrm{~cm}^{-1} . \mathrm{UV}-\mathrm{Vis}$ (acetonitrile): $\lambda_{\max }=498 \mathrm{~nm}, \varepsilon_{\max }=2.0 \times 10^{4} . \mathrm{HRMS}[\mathrm{EI}]:$ found 519.18830, $\mathrm{C}_{30} \mathrm{H}_{25} \mathrm{~N}_{5} \mathrm{O}_{4}$ requires 519.19065.

Pyrrole azocrown ether 5. The synthesis was performed by an analogous method to that used to synthesize $\mathbf{3}$ or $\mathbf{4}$ starting from 12. The coupling reaction was carried out over 2 $\mathrm{h}$ at $10^{\circ} \mathrm{C}$ and $2 \mathrm{~h}$ at room temperature. The product was isolated by column chromatography using a methylene chloride-acetone (30:1) mixture as eluent. It was crystallized from acetone/hexane. Yield $13 \%, \mathrm{mp} 159-161^{\circ} \mathrm{C} . \mathrm{TLC}: \mathrm{R}_{\mathrm{F}}=0.46$ 
(methylene chloride - acetone 50:1). ${ }^{1} \mathrm{H} \mathrm{NMR}\left(\mathrm{CDCl}_{3}\right)$ : $1.35(18 \mathrm{H}, \mathrm{s}) ; 3.88(4 \mathrm{H}, \mathrm{s})$; 3.95-4.02 (4H, m); 4.30 - $4.37(4 \mathrm{H}, \mathrm{m}) ; 6.96(2 \mathrm{H}, \mathrm{d}, J=8.8 \mathrm{~Hz}) ; 7.19(2 \mathrm{H}, \mathrm{s}) ; 7.41(2 \mathrm{H}$, $\left.\mathrm{dd}, J_{l}=8.3 \mathrm{~Hz}, J_{2}=1.95 \mathrm{~Hz}\right) ; 7.80(2 \mathrm{H}, \mathrm{d}, J=1.95 \mathrm{~Hz}) ; 12.47(1 \mathrm{H}, \mathrm{bs})$. IR (nujol): $3583,3493,1599,1500,1259,1214,1180,1139,1106,1024,952,899,723 \mathrm{~cm}^{-1}$. UVVis (acetonitrile): $\lambda_{\max }=508 \mathrm{~nm}, \varepsilon_{\max }=1.4 \times 10^{4} . \mathrm{HRMS}[\mathrm{EI}]:$ Found 533.29929; $\mathrm{C}_{30} \mathrm{H}_{39} \mathrm{~N}_{5} \mathrm{O}_{4}$ requires 533.30021.

\section{Competitive mixed-metal transport experiments}

Bulk membrane transport experiments were carried out exactly as described elsewhere [10]; the aqueous source phase was buffered at $\mathrm{pH} 4.9 \pm 0.1\left(10 \mathrm{~cm}^{3}\right.$; acetic acid/sodium acetate buffer) containing a mixture of cobalt(II), nickel(II), copper(II), zinc(II), cadmium(II), silver(I) and lead(II) nitrates, each at concentration of $10^{-2} \mathrm{~mol} \mathrm{dm}{ }^{-3}$. The chloroform phase $\left(50 \mathrm{~cm}^{3}\right)$ contained the pyrrole azocrowns $1,2,3$, or $4\left(1 \times 10^{-3} \mathrm{~mol}\right.$ $\left.\mathrm{dm}^{-3}\right)$ and hexadecanoic acid $\left(4 \times 10^{-3} \mathrm{~mol} \mathrm{dm}^{-3}\right)$. The receiving phase $\left(30 \mathrm{~cm}^{3}\right)$ was buffered at $\mathrm{pH} 3.0 \pm 0.1$ (formic acid/sodium formate buffer). Transport experiments were terminated after $24 \mathrm{~h}$ and atomic absorption spectroscopy was used to determine the amount of metal ion transported over this period. The average results of two independent runs are shown in Table 1, with individual values being typically within \pm $5 \%$ of the mean value.

\section{Spectrophotometric studies of the complexation of metal cations with macrocycles}

\section{$1-4$ in solution}

A representative set of semi-quantitative complex formation experiments were performed in acetonitrile. UV-Vis titration was carried out by addition of metal 
perchlorate to the crown ether solution. The composition of species under equilibrium was determined using Job's (continuous variation) method [11]. The UV-Vis titration data analysis was performed with the OPIUM program [12].

\section{Ion-selective membrane electrodes}

The solvent polymeric membranes evaluated for ion response are composed of ionophore $(\mathbf{1}$ - 5) $1.5 \mathrm{mg}$, potassium tetrakis-p-chlorophenylborate (KTpClPB) $0.75 \mathrm{mg}$, plasticizer (o-nitrophenyl-octyl ether - o-NPOE, bis-butylpentyl adipate - BBPA or bisethylhexyl phthalate - DOP) $0.1 \mathrm{~cm}^{3}$ and $50 \mathrm{mg}$ PVC. The membrane components were dissolved in freshly distilled THF $\left(2 \mathrm{~cm}^{3}\right)$. This solution was placed in a glass ring (15 mm i.d.) over a glass plate. After evaporation of the solvent overnight, the resulting membrane was peeled from the glass mold and discs of $7 \mathrm{~mm}$ diameter were cut out. These membrane discs were mounted in conventional ISE electrode bodies (IS 561 type; SPR Moeller) for EMF measurements. A Radelkis OP-08201 reference electrode was employed and various bridging electrolytes.

All measurements were performed at ambient temperature $\left(20^{\circ} \mathrm{C}\right)$ using a galvanic cell of the following form:

$\mathrm{Ag}\left|\mathrm{AgCl}_{(\mathrm{s})}\right| 1 \mathrm{M} \mathrm{KCl} \mid$ bridge electrolyte $\mid$ sample $\mid$ ion-selective membrane $\mid$ internal electrolyte $\left|\mathrm{AgCl}_{(\mathrm{s})}\right| \mathrm{Ag}$

The bridge electrolytes were: $0.1 \mathrm{M} \mathrm{KNO}_{3}$ for electrodes with $o$-NPOE or DOP plasticizers and $1 \mathrm{M} \mathrm{NH}_{4} \mathrm{NO}_{3}$ for electrodes with BBPA.

The composition of the internal electrolyte is shown in Table 3. Electrodes were conditioned in $10^{-2} \mathrm{M} \mathrm{Pb}\left(\mathrm{NO}_{3}\right)_{2}$ solution for 2 days, then soaked for $1 \mathrm{~h}$ in $\mathrm{HNO}_{3}$ solution ( $\mathrm{pH}$ 5.0) before undertaking measurements. All measurement were performed 


\section{RESULTS AND DISCUSSION}

Previously macrocycle mediated transport experiments [14] have had as their focus silver/lead discrimination - metals that occur together in nature $[15,16]$. From an environmental point of view ideally $\mathrm{Zn}^{2+}$ should not compete with the removal of $\mathrm{Pb}^{2+}$ (or $\mathrm{Cd}^{2+}$ ) [17]. Indeed, highly selective separation of lead in the presence of zinc has been achieved using tetrakis-(carboxymethyl)-tetrakis-(p-tert-octyl)calix[4]arene [18]. In another study, preferred transport of lead over cadmium and zinc employing polymer inclusion membranes doped with calix[4]-crown-6 derivatives has also been observed [19]. High $\mathrm{Pb}^{2+}$ transport selectivity over $\mathrm{Fe}^{3+}, \mathrm{Cu}^{2+}$ and $\mathrm{Zn}^{2+}$ has been reported for binary metal systems containing equimolar ratios of lead and the competing cations using dicyclohexano-18-crown-6, dithia-18-crown-6 or diketopyridino-18-crown-6 as ionophores [20]. Contrary to the above observations, lead transport has been shown to be less efficient for systems employing neutral thia- and azacrown ethers relative to other transition and post-transition metal cations [21].

Our competitive transport experiments were performed as described [10] using 1 - 4 (Fig. 1) as the ionophores. Palmitic acid was added to the chloroform membrane in four-fold excess $\left(4 \times 10^{-3} \mathrm{~mol} \mathrm{dm}^{3}\right)$ relative to the concentration of crown ether $\left(10^{-3}\right.$ mol $\mathrm{dm}^{3}$ ) present. The presence of the palmitic acid avoids the need to co-transport nitrate ion from the aqueous source phase (the palmitic acid loses a proton to the aqueous phase). Palmitic acid at the above concentration in the absence of macrocycle has been shown not to transport any of the metals listed in Table 1 [10]. Normally, we 
have arbitrarily chosen a flux of $20 \times 10^{-7} \mathrm{~mol} / 24 \mathrm{~h}$ as the value below which experimental error means that a given result is uncertain. The experimental values for cations $(\mathrm{Cu}, \mathrm{Cd}, \mathrm{Co}, \mathrm{Ni}, \mathrm{Zn})$ other than lead are all much lower then the $20 \times 10^{-7}$ limit while the value for silver is only marginally lower for system employing 4.

Under the conditions employed compounds $\mathbf{2 , 3}$, and $\mathbf{4}$ are moderately effective ionophores for $\mathrm{Pb}^{2+}$ relative to the other metal ions present. The respective lead(II) fluxes are 33,26 and $21 \times 10^{-7} \mathrm{~mol} / 24 \mathrm{~h}$ while 1 transports this ion to a lesser extent $\left(\sim 15 \times 10^{-7} \mathrm{~mol} / 24 \mathrm{~h}\right)$. It is noted that monovalent silver (ionic radius $1.26 \AA$ ) is negligibly transported by $\mathbf{1}, \mathbf{2}$, and $\mathbf{3}$. However, in the absence of further studies it appears inappropriate to speculate about the reason for this behavior.

Table 1 Average fluxes of metal cations promoted by crown ethers $1-4$

\begin{tabular}{|c|c|c|c|c|c|c|c|}
\hline Ligand & \multicolumn{7}{|c|}{ Average fluxes J*10 $0^{7}, \mathrm{~mol} / 24 \mathrm{~h}$} \\
\hline & $\mathrm{Pb}$ & $\mathrm{Ag}$ & $\mathrm{Cu}$ & $\mathrm{Cd}$ & $\mathrm{Co}$ & $\mathrm{Ni}$ & $\mathrm{Zn}$ \\
\hline $\mathbf{1}$ & 15.0 & 1.5 & 0.5 & 0.1 & 0.5 & 0.4 & 0.3 \\
\hline $\mathbf{2}$ & 32.9 & 1.1 & 1.65 & 0.1 & 0.5 & 0.5 & 0.55 \\
\hline $\mathbf{3}$ & 25.8 & 1.25 & 1.35 & 0.1 & 0.55 & 0.35 & 0.4 \\
\hline $\mathbf{4}$ & 21.1 & 12.8 & 0.25 & 0.15 & 2.1 & 0.55 & 0.75 \\
\hline
\end{tabular}

The differences in transport fluxes listed in Table 1 will very likely be influenced by a number of factors. These include differences in aqueous/organic partition coefficients, variation in the complexation/decomplexation rates between systems, different rates of metal ion diffusion across the aqueous/organic interfaces and the absolute magnitudes 
of the respective stability constants. For example, in the latter case $\mathrm{K}$ values that are too high or too low can both inhibit the transport process. Similarly, slow complexation rates [c.f. 22,23] have been implicated previously in selective transport behavior [24]. In view of the above, an attempt was made to investigate spectrophotometrically the relative rates of formation of selected metal complexes involved in the present study with $1-4$. Since measurements in chloroform tended to be troublesome, a representative set of semi-quantitative complex formation experiments were performed in acetonitrile.

It was found that lead(II) ion appears completely complexed within the time scale of the initial spectrophotometric measurement. In the presence of lead(II) perchlorate the color changes from red to deep blue. The measured absorption spectra exhibit a well defined isosbestic point which is consistent with the presence of only two UV-Vis active species: ligand and its complex. Spectral changes upon titration with lead(II) perchlorate are exemplified in Fig. 2 for compounds $\mathbf{1}$ (left) and $\mathbf{2}$ (right), corresponding to 18- and 21-membered macrocycle ring sizes, respectively.
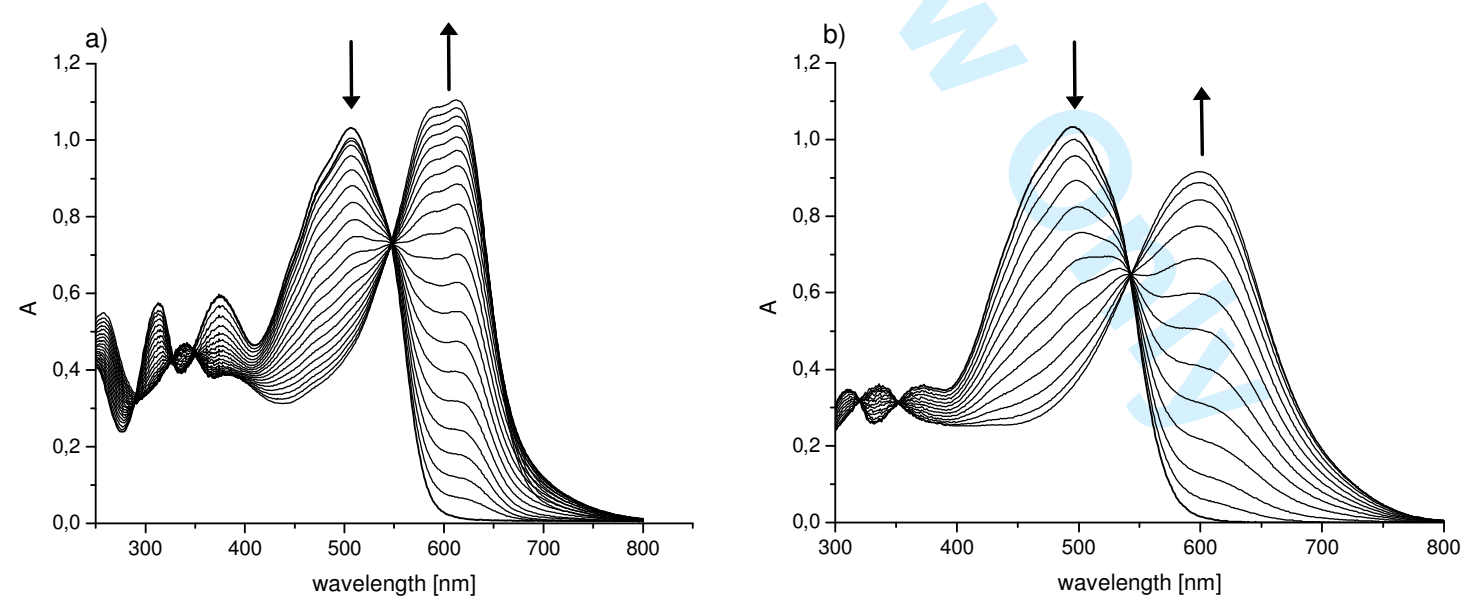

Figure 2 UV-Vis titration of crown ethers (starting volume $2.3 \mathrm{~mL}$ ) with lead(II) perchlorate (titration step $0.01 \mathrm{~mL}$ ): a) crown 1 (initial ligand concentration $\mathrm{c}_{\mathrm{L}}=4 \times 10^{-5} \mathrm{~mol} \mathrm{dm}^{-3} ; \mathrm{c}_{\mathrm{Pb}}=4.2 \times 10^{-3} \mathrm{~mol} \mathrm{dm}^{-3}$ ), 
and b) crown $2\left(\mathrm{c}_{\mathrm{L}}=3.6 \times 10^{-5} \mathrm{~mol} \mathrm{dm}^{-3} ; \mathrm{c}_{\mathrm{Pb}}=4.2 \times 10^{-3} \mathrm{~mol} \mathrm{dm}^{-3}\right)$. The initial spectrum is that of the starting ligand and the final corresponds to the complexed form.

Fig. 3 presents Job's plots for compounds $\mathbf{1}$ and $\mathbf{2}$ with apparent $x_{\max }$ value of 0.4, corresponding to formation of a $2: 3$ (metal: ligand) complex (cf. "club-sandwich" complex [25]).
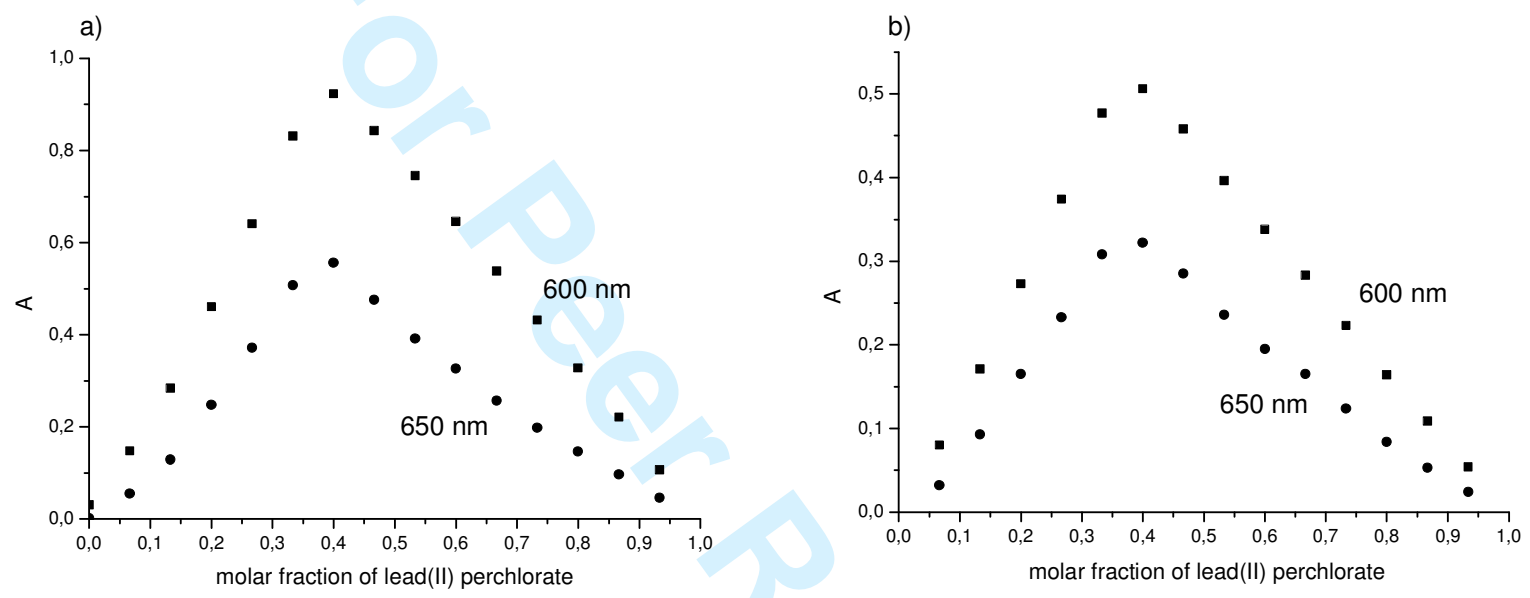

Figure 3 Job's plot for lead(II) complexation of compounds 1 (a) and 2 (b) at different wavelengths.

Data analyses for the UV-Vis titration of ligand solutions with lead(II) perchlorate in acetonitrile were performed assuming the formation of one complex at equilibrium using the OPIUM program [12]. Best fit was obtained for 2:3 (metal:ligand) stoichiometry. The determined stability constants, for the assumed stoichiometry, and their standard deviations are listed in Table 2.

Table 2 Stability constants of crown ethers 1 - 4 complexes with lead(II) in acetonitrile at $25 \pm 0.5^{\circ} \mathrm{C}$.

\begin{tabular}{|lcccc|}
\hline Crown ether & $\mathbf{1}$ & $\mathbf{2}$ & $\mathbf{3}$ & $\mathbf{4}$ \\
\hline Log K & & & & \\
\hline $\mathrm{L3Pb2}$ & $18.1 \pm 0.01$ & $21.1 \pm 0.09$ & $18.3 \pm 0.01$ & $19.5 \pm 0.04$ \\
\hline
\end{tabular}


The relatively high values of the stability constants for the lead(II) complexes are comparable to each other and do not substantially depend on the size of macrocycle.

Similar experiments were carried out for zinc(II), nickel(II), and cobalt(II). Changes in the absorption spectra upon titration of compound $\mathbf{2}$ with zinc(II) perchlorate are shown in Fig. 4. Addition of zinc(II) salt resulted in noticeable changes in this ligand's absorption spectrum; however, the observed changes indicated that in this case the system equilibrates much slower than with lead(II). The collection of spectra labeled 2 were obtained after consecutive addition of appropriate amounts of zinc salt solution; the latter resulted in an accompanied color change from red to purple. Spectrum 3 obtained for the final solution after 72 hours does not intersect the isosbestic point (solution color had changed to purple-violet). This thus indicates that a new species forms on allowing the solution to stand for an extended period.



Figure 4 Changes in the absorption spectra upon titration of compound $2\left(4.9 \times 10^{-5} \mathrm{~mol} \mathrm{dm}^{-3}, 2.3 \mathrm{~mL}\right)$ with zinc(II) perchlorate $\left(8.3 \times 10^{-3} \mathrm{~mol} \mathrm{dm}^{-3}\right.$, titration step $\left.0.01 \mathrm{~mL}\right)$ : 1 - free ligand; 2 - spectra registered within three minutes after addition of consecutive portions of $0.01 \mathrm{~mL}$ of the zinc salt. Spectrum 3 was registered 72 hours after addition of the total volume $\left(0.1 \mathrm{~cm}^{3}\right)$ of zinc perchlorate solution. 
A similar experiment involving nickel(II) leads to only slow changes in the spectrum of compound $\mathbf{2}$, as might be expected in view of the well documented more inert nature of this ion. In this case monitoring of the spectrum over time indicated slow kinetics. The spectral changes are shown in Fig. 5. The series of spectra (2) registered at 30 minutes intervals from the initial mixture of ligand and nickel salt show an increasing concentration of complex. Spectrum 3 registered after 10 hours does not pass through the isosbestic point and once again indicates formation of a further species.

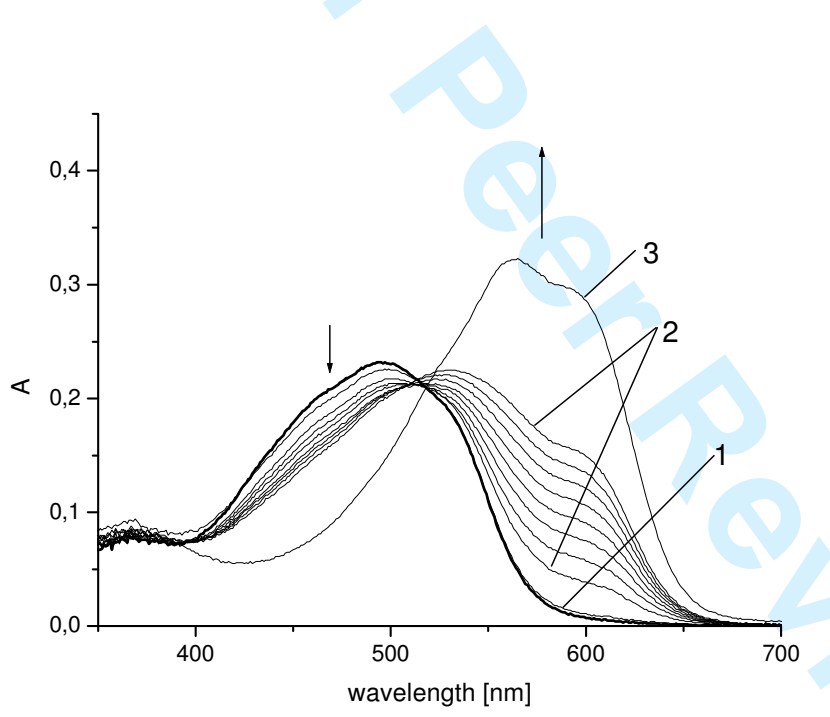

Figure 5 Spectral changes indicating slow binding of nickel(II) to crown ether $2\left(\mathrm{c}=7.32 \times 10^{-6} \mathrm{~mol}\right.$ $\left.\mathrm{dm}^{-3}, \mathrm{v}=2.3 \mathrm{~cm}^{3}\right)$ in acetonitrile on addition of nickel perchlorate $\left(\mathrm{c}=1.03 \times 10^{-2} \mathrm{~mol} \mathrm{dm}{ }^{-3}, \mathrm{v}=0.01\right.$ $\mathrm{cm}^{3}$ ). The initial spectrum (1) was obtained two minutes after addition of the salt solution. Consecutive spectra (2) were registered at $30 \mathrm{~min}$. intervals after this. Spectrum 3 was taken after $10 \mathrm{~h}$.

Analogous experiments employing cobalt(II) also showed slow kinetics of complexation with 2 . However, silver(I) cation binds instantly to this ligand in acetonitrile. Experiments with cadmium(II) were not performed due to solubility restrictions. 
Several neutral compounds with oxygen, nitrogen and sulfur donor atoms have been examined as ionophores for lead selective electrodes [cf. 26]. The selectivity observed for lead transport and substantial stability constants obtained for the lead complexes prompted us to study the behavior of ion-selective membrane electrodes doped with $\mathbf{1}$ - 4. Initially, preliminary screening aimed at optimizing the composition of the membrane was carried out. This involved varying the plasticizer, the amounts of ionophore and lipophilic salt present and the composition of the internal electrolyte. On the basis of these preliminary studies, membranes of composition: $1.5 \mathrm{mg}$ ionophore, $0.75 \mathrm{mg}$ lipophilic salt KTpCIPB per $0.1 \mathrm{~cm}^{3}$ plasticizer and $50 \mathrm{mg}$ PVC were employed; selectivities were then compared for membranes of this composition but incorporating different plasticizers ( $o$-NPOE, BBPA and DOP). The selectivity coefficients were determined using the Separate Solution Method [13] employing metal nitrate solutions of $10^{-3}$ activity at $\mathrm{pH} 5.3 \pm 0.1$. The selectivity coefficients are summarized in Fig. 6. Other properties of the electrodes employed are summarized in Table 3.

Compound 1 was observed to be an inefficient ionophore as it was found to readily crystallize in the membrane and in addition leaked to the aqueous solution in the presence of $\mathrm{Pb}^{2+}$ ions. Compound $\mathbf{2}$ also shows a tendency to crystallize in the membrane; $1.5 \mathrm{mg}$ of this ionophore added to form the membrane was found to be the limit if crystallization was to be avoided. Once again, ionophore $\mathbf{2}$ was also found to leak from the membrane into the aqueous phase when the membrane was not doped with the lipophilic salt. Nevertheless, both $\mathbf{3}$ and $\mathbf{4}$ do not crystallize and are retained in the membrane under the above conditions. Electrodes incorporating $\mathbf{1}-\mathbf{4}$ and BBPA or DOP plasticizers show cationic ISE characteristics but the selectivities are not very 
high. Membranes with compounds 1 and $\mathbf{4}$ (containing $1.5 \mathrm{mg}$ ionophore and $0.75 \mathrm{mg}$ lipophilic salt) and $o$-NPOE were found to bind $\mathrm{Pb}^{2+}$ non-reversibly.

Amongst macrocycles $\mathbf{1}-\mathbf{4}$, electrodes based on $\mathbf{2}$ and $\mathbf{3}$ (KTpCIPB as lipophilic salt and $o$-NPOE as plasticizer) were found to possess the best ISE properties (Fig. 6), while a characteristic of electrodes employing $\mathbf{3}$ is that they appeared the most stable.



Electrode number

Figure 6 Selectivity coefficients $\log K_{P b, X}^{p o t}$ for membrane electrodes doped with compound $\mathbf{2 , 3}$ or $\mathbf{5}$ (plasticizer: A - o-NPOE, B - BBPA, C - DOP). 0 - "blank electrode".

Unfortunately, as mentioned above, $\mathbf{2}$ showed a tendency to crystallize and substantial leakage from the membrane also occurred. In view of this ionophore $\mathbf{5}$ was synthesized (Scheme 1) as it was predicted to show higher lipophilicity, better solubility 
in the membrane components as well as a tendency not to crystallize. In fact, membranes based on this compound (containing $o$-NPOE as plasticizer) were subsequently demonstrated to have the best properties as exemplified by the results shown in Fig. 6. These preliminary studies showed that in the absence of $\mathrm{Ag}^{+}$ions the electrode is selective towards $\mathrm{Pb}^{2+}$ relative to the other cations employed for the transport experiments as well as the alkali and alkaline earth metal cations investigated.

Table 3 Plasticizers, internal electrolytes, linear responses and slopes for electrodes based on compound $\mathbf{2}, \mathbf{3}$ and $\mathbf{5}$.

\begin{tabular}{|c|c|c|c|c|}
\hline $\begin{array}{c}\text { Electrode } \\
\text { number }\end{array}$ & $\begin{array}{c}\text { Ionophore } \\
\text { (plasticizer) }\end{array}$ & $\begin{array}{c}\text { Internal electrolyte } \\
{\left[\mathrm{mol} \mathrm{dm}^{3}\right]}\end{array}$ & $\begin{array}{c}\text { Range of linear } \\
\text { response }[\log \mathrm{a}]\end{array}$ & $\begin{array}{c}\text { Slope /decade } \\
{[\mathrm{mV}]}\end{array}$ \\
\hline $\mathbf{2 A}$ & $\mathbf{2}$ (NPOE) & $\mathrm{PbCl}_{2} 5 \times 10^{-3}$ & $-6.0--1.8$ & 34.2 \\
\hline $\mathbf{2 B}$ & $\mathbf{2}$ (BBPA) & $\mathrm{PbCl}_{2} 5 \times 10^{-3}$ & $-5.0--2.6$ & 25.0 \\
\hline $\mathbf{2 C}$ & $\mathbf{2}$ (DOP) & $\mathrm{KCl} 10^{-2}$ & $-6.0--2.0$ & 32.0 \\
\hline $\mathbf{3 A}$ & $\mathbf{3}$ (NPOE) & $\mathrm{PbCl}_{2} 5 \times 10^{-3}$ & $-5.5--1.8$ & 32.2 \\
\hline 3B & $\mathbf{3}$ (BBPA) & $\mathrm{PbCl}_{2} 5 \times 10^{-3}$ & $-5.5--2.6$ & 30.0 \\
\hline 3C & $\mathbf{3}$ (DOP) & ${\mathrm{KCl} 10^{-2}}$ & $-5.0--1.8$ & 31.0 \\
\hline 5A & $\mathbf{3}$ (NPOE) & $\mathrm{PbCl}_{2} 5 \times 10^{-3}$ & $-5.0--1.8$ & 28.5 \\
\hline
\end{tabular}

\section{Conclusions}

The stability constants, observed transport fluxes and properties of the ion-selective membrane electrodes collectively indicate that macrocyclic compounds of the present type bearing a pyrrole residue together with oxygen and azo donor atoms show an inherent tendency towards $\mathrm{Pb}^{2+}$ cation selectivity, although possible interference from silver may occur. 


\section{Acknowledgements}

The Authors E.L., E.W.-W. and J.F.B. kindly acknowledge support of this study from the State Committee for Scientific Research, Grant No. 3 T09A 151 27. Technical assistance by E. Mucha, A. Krajewska and J. Żochowska is also acknowledged. LFL and M. F-M thank the Australian Research Council.

\section{References}

[1] Luboch, E.; Bilewicz, R,; Kowalczyk, M.; Wagner-Wysiecka, E.; Biernat, J. F. in: Advances in Supramolecular Chemistry, Vol. 9; Gokel G. W., Ed.; Cerberus Press: South Miami, 2003; p. 71.

[2] Wagner-Wysiecka, E.; Luboch, E.; Kowalczyk, M.; Biernat, J. F. Tetrahedron 2003, 59, 4415.

[3] Skwierawska, A.; Inerowicz, H. D.; Biernat, J. F. Tetrahedron Lett. 1998, 39, 3057.

[4] Inerowicz, H. D.; Skwierawska, A.; Biernat, J. F. Supramol. Chem. 2000, 12, 111.

[5] Slyn'ko, N. M.; Tormyshev, V. M. Russ. J. Org. Chem. 2000, 36, 254.

[6] Baker, B. R.; Lourens, G. J. J. Med. Chem. 1968, 11, 26.

[7] Weber, E.; Ahrendt, J.; Brueck, F.J.; Reddy, P. Y.; Chacko, K. K. J. Pract. Chem. 1993, 3, 235.

[8] Zawisza, I.; Bilewicz, R.; Luboch, E.; Biernat, J. F. Supramol. Chem. 1998, 9, 227.

[9] Luboch, E.; Biernat, J. F.; Simonov, Yu. A.; Dvorkin, A. A. Tetrahedron 1998, 54, 4977.

[10] Kim, J.; Ahn, T.-H.; Lee, M.; Leong, A. J.; Lindoy, L. F.; Rumbel, B. R.; Skelton, B.W.; Strixner, T.; Wei, G.; White, A. H. J. Chem. Soc., Dalton Trans. 2002, 3993.

[11] Job, P. Ann. Chim. Phys. 1928, 9, 113.

[12] Kyvala, M.; Lukeš, I.: program package "OPIUM" available (free of charge) on http://www.natur.cuni.cz/ kyvala/opium.html.

[13] Umezawa, Y.; Umezawa, K.; Saito, H. Pure \& Appl. Chem. 1995, 67, 507.

[14] Yordanov, A. T.; Roundhill, D. M. Coord. Chem. Rev. 1998, 170, 93.

[15] Adam, K. R.; Baldwin, D. S.; Bashall, A.; Lindoy, L. F.; McPartlin, M.; Powell, H. R. J. Chem. Soc., Dalton Trans. 1994, 237. 
[16] Adam, K. R.; Baldwin, D. S.; Duckworth, P.A.; Lindoy, L. F.; McPartlin, M.; Bashall, A.; Powell, H. R.; Tasker, P.A. J. Chem. Soc., Dalton Trans. 1995, 1127.

[17] Caiazza, D.; Lincoln, S. F.; Ward, A. D. Inorg. Chim. Acta 2004, 357, 716.

[18] Ohto, K.; Fujimoto, Y.; Inoue, K. Anal. Chim. Acta 1999, 387, 61.

[19] M. Ulewicz, M.; Bocheńska, M.; Lesińska, U.; Walkowiak, W. Physicochemical Problems of Mineral Processing 2005, 39, 107.

[20] Lamb, J. D.; Izatt, R. M.; Robertson, P. A.; Christensen, J. J. J. Am. Chem. Soc. 1980, 102, 2452.

[21] Cho, M.-H.; Chun, H.-S.; Kim, J.-H.; Rhee, C.-H.; Kim, S.-J. Bull. Korean Chem. Soc. 1991, 12, 474.

[22] Cram, D. J.; Carmack, R. A.; Helgeson, R. C. J. Am. Chem. Soc. 1988, 110, 571.

[23] Chapoteau, E.; Czech, B. P.; Kumar, A.; Zazulak, W. J. Incl. Phenom. 1993, 16, 367.

[24] Fyles, T. M. J. Chem. Soc., Faraday Trans. I 1986, 617.

[25] Pedersen, C. J. J. Am. Chem. Soc. 1970, 92, 386.

[26] Bühlmann, P.; Pretsch, E.; Bakker, E. Chem. Rev. 1998, 98, 1593. 
TABLES

10

Table 1 Average fluxes of metal cations promoted by crown ethers $1-4$

\begin{tabular}{|c|c|c|c|c|c|c|c|}
\hline Ligand & \multicolumn{7}{|c|}{ Average fluxes J*10 $10^{7}, \mathrm{~mol} / 24 \mathrm{~h}$} \\
\hline & $\mathrm{Pb}$ & $\mathrm{Ag}$ & $\mathrm{Cu}$ & $\mathrm{Cd}$ & $\mathrm{Co}$ & $\mathrm{Ni}$ & $\mathrm{Zn}$ \\
\hline $\mathbf{1}$ & 15.0 & 1.5 & 0.5 & 0.1 & 0.5 & 0.4 & 0.3 \\
\hline $\mathbf{2}$ & 32.9 & 1.1 & 1.65 & 0.1 & 0.5 & 0.5 & 0.55 \\
\hline $\mathbf{3}$ & 25.8 & 1.25 & 1.35 & 0.1 & 0.55 & 0.35 & 0.4 \\
\hline $\mathbf{4}$ & 21.1 & 12.8 & 0.25 & 0.15 & 2.1 & 0.55 & 0.75 \\
\hline
\end{tabular}

Table 2 Stability constants of crown ethers 1- 4 complexes with lead(II) in acetonitrile at $25 \pm 0.5^{\circ} \mathrm{C}$.

\begin{tabular}{|lcccc|}
\hline Crown ether & $\mathbf{1}$ & $\mathbf{2}$ & $\mathbf{3}$ & $\mathbf{4}$ \\
\hline Log K & & & & $19.5 \pm 0.04$ \\
\hline
\end{tabular}

Table 3 Plasticizers, internal electrolytes, linear responses and slopes for electrodes based on compound $\mathbf{2}, \mathbf{3}$ and $\mathbf{5}$.

\begin{tabular}{|c|c|c|c|c|}
\hline $\begin{array}{c}\text { Electrode } \\
\text { number }\end{array}$ & $\begin{array}{c}\text { Ionophore } \\
\text { (plasticizer) }\end{array}$ & $\begin{array}{c}\text { Internal electrolyte } \\
{\left[\mathrm{mol} \mathrm{dm}^{3}\right]}\end{array}$ & $\begin{array}{c}\text { Range of linear } \\
\text { response }[\log \mathrm{a}]\end{array}$ & $\begin{array}{c}\text { Slope /decade } \\
{[\mathrm{mV}]}\end{array}$ \\
\hline $\mathbf{2 A}$ & $\mathbf{2}$ (NPOE) & $\mathrm{PbCl}_{2} 5 \times 10^{-3}$ & $-6.0--1.8$ & 34.2 \\
\hline $\mathbf{2 B}$ & $\mathbf{2}$ (BBPA) & $\mathrm{PbCl}_{2} 5 \times 10^{-3}$ & $-5.0--2.6$ & 25.0 \\
\hline $\mathbf{2 C}$ & $\mathbf{2}$ (DOP) & $\mathrm{KCl} 10^{-2}$ & $-6.0--2.0$ & 32.0 \\
\hline $\mathbf{3 A}$ & $\mathbf{3}$ (NPOE) & $\mathrm{PbCl}_{2} 5 \times 10^{-3}$ & $-5.5--1.8$ & 32.2 \\
\hline
\end{tabular}




\begin{tabular}{|c|c|c|c|c|}
\hline 3B & $\mathbf{3}$ (BBPA) & $\mathrm{PbCl}_{2} 5 \times 10^{-3}$ & $-5.5--2.6$ & 30.0 \\
\hline $\mathbf{3 C}$ & $\mathbf{3}$ (DOP) & $\mathrm{KCl} 10^{-2}$ & $-5.0--1.8$ & 31.0 \\
\hline $\mathbf{5 A}$ & $\mathbf{3}$ (NPOE) & $\mathrm{PbCl}_{2} 5 \times 10^{-3}$ & $-5.0--1.8$ & 28.5 \\
\hline
\end{tabular}

\section{FIGURES}


Figure 1 Structures of macrocycles studied. 

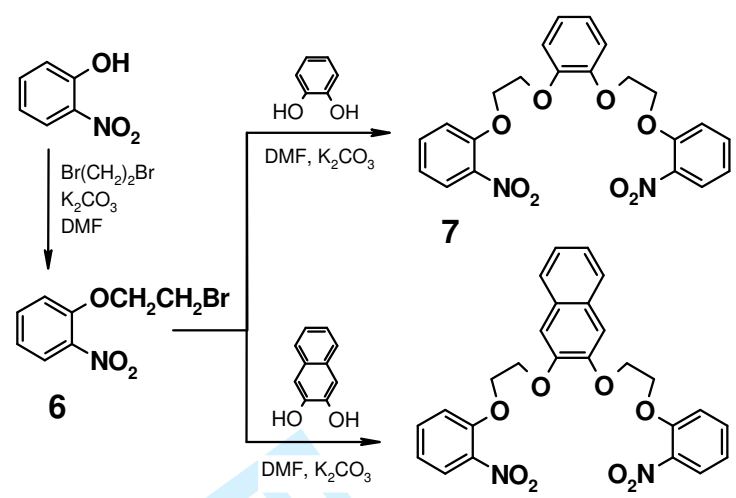<smiles>CN(CCOc1ccccc1N)c1ccccc1OCCOc1ccccc1OCCOc1ccccc1N</smiles>

a) $\mathrm{NaNO}_{2}, \mathrm{HCl}$

b) pyrrole

Crown 3

8

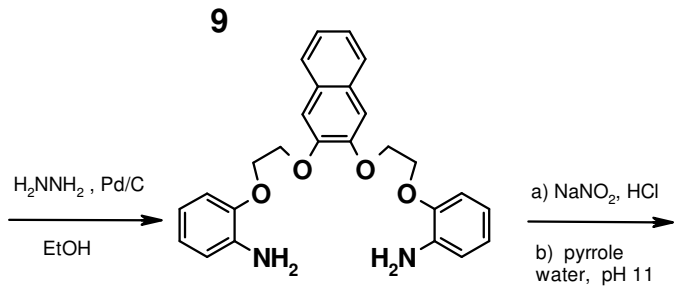

Crown 4

10<smiles>CCOc1ccc(C(C)(C)C)cc1[N+](=O)[O-]</smiles>

11<smiles>COCOc1ccc(C(C)(C)C)cc1[N+](=O)[O-]</smiles>$$
\text { (a) }
$$

Scheme 1 Synthesis of crowns $\mathbf{3}$ - 5. The final step in each case involved formation of a bis-diazonium intermediate.
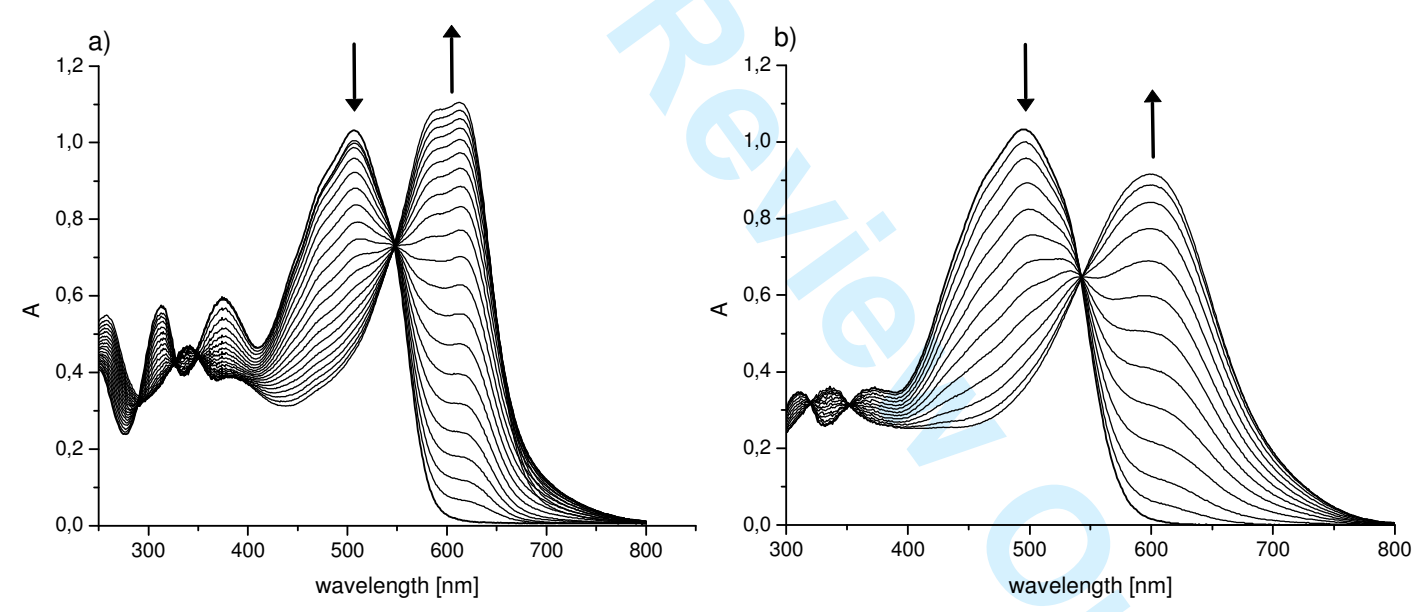

Figure 2 UV-Vis titration of crown ethers (starting volume $2.3 \mathrm{~mL}$ ) with lead(II) perchlorate (titration step $0.01 \mathrm{~mL}$ ): a) crown 1 (initial ligand concentration $\mathrm{c}_{\mathrm{L}}=4 \times 10^{-5} \mathrm{~mol} \mathrm{dm}^{-3} ; \mathrm{c}_{\mathrm{Pb}}=4.2 \times 10^{-3} \mathrm{~mol} \mathrm{dm}^{-3}$ ), and b) crown $2\left(\mathrm{c}_{\mathrm{L}}=3.6 \times 10^{-5} \mathrm{~mol} \mathrm{dm}^{-3} ; \mathrm{c}_{\mathrm{Pb}}=4.2 \times 10^{-3} \mathrm{~mol} \mathrm{dm}^{-3}\right)$. The initial spectrum is that of the starting ligand and the final corresponds to the complexed form. 

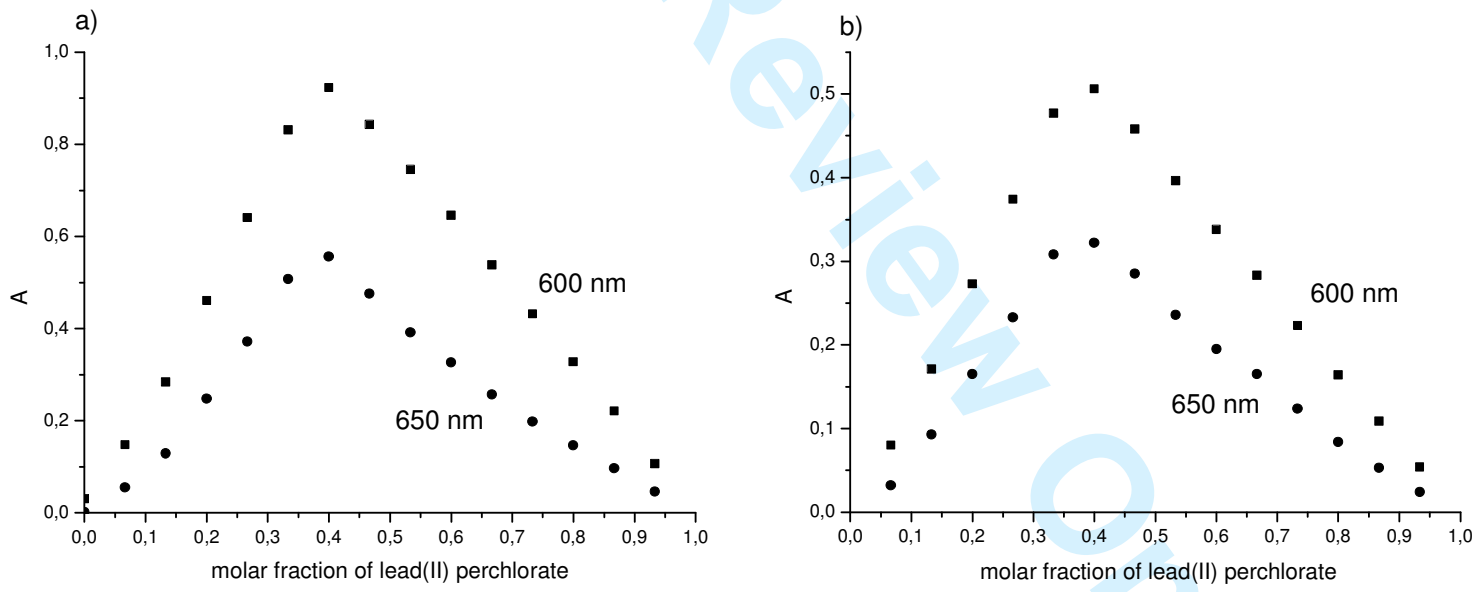

Figure 3 Job's plot for lead(II) complexation of compounds $\mathbf{1}$ (a) and $\mathbf{2}$ (b) at different wavelengths. 


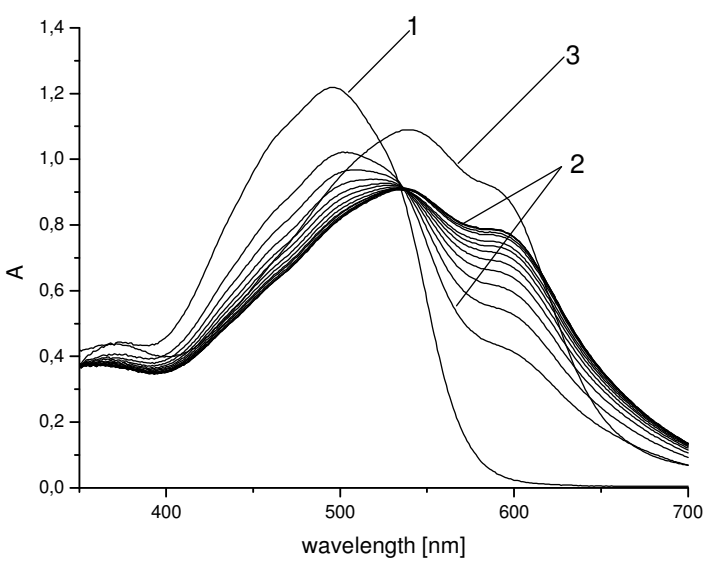

Figure 4 Changes in the absorption spectra upon titration of compound $2\left(4.9 \times 10^{-5} \mathrm{~mol} \mathrm{dm}^{-3}, 2.3 \mathrm{~mL}\right)$ with zinc(II) perchlorate $\left(8.3 \times 10^{-3} \mathrm{~mol} \mathrm{dm}^{-3}\right.$, titration step $\left.0.01 \mathrm{~mL}\right)$ : 1 - free ligand; 2 - spectra registered within three minutes after addition of consecutive portions of $0.01 \mathrm{~mL}$ of the zinc salt. Spectrum 3 was registered 72 hours after addition of the total volume $\left(0.1 \mathrm{~cm}^{3}\right)$ of zinc perchlorate solution.

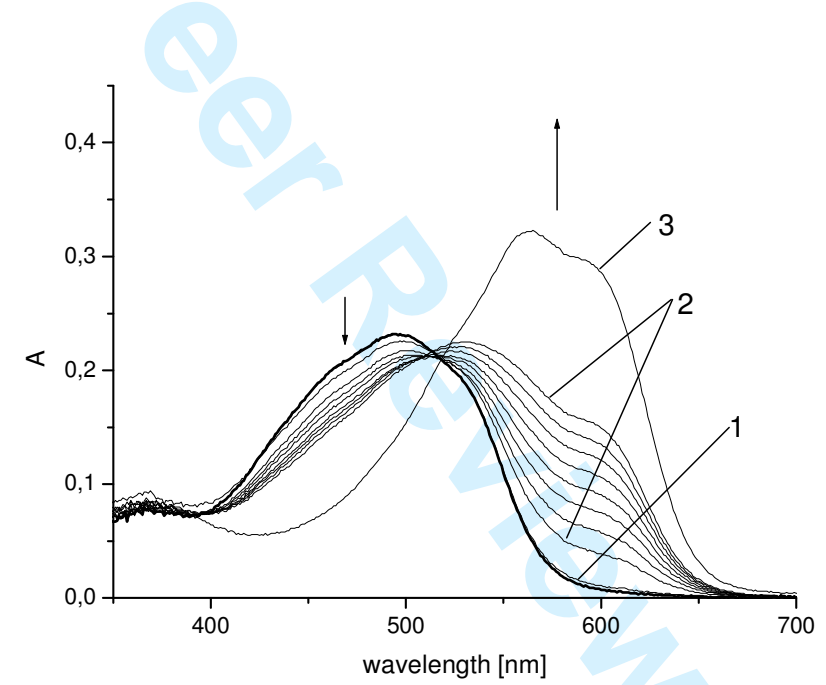

Figure 5 Spectral changes indicating slow binding of nickel(II) to crown ether $2\left(\mathrm{c}=7.32 \times 10^{-6} \mathrm{~mol}\right.$ $\left.\mathrm{dm}^{-3}, \mathrm{v}=2.3 \mathrm{~cm}^{3}\right)$ in acetonitrile on addition of nickel perchlorate $\left(\mathrm{c}=1.03 \times 10^{-2} \mathrm{~mol} \mathrm{dm}{ }^{-3}, \mathrm{v}=0.01\right.$ $\mathrm{cm}^{3}$ ). The initial spectrum (1) was obtained two minutes after addition of the salt solution. Consecutive spectra (2) were registered at $30 \mathrm{~min}$. intervals after this. Spectrum 3 was taken after $10 \mathrm{~h}$. 


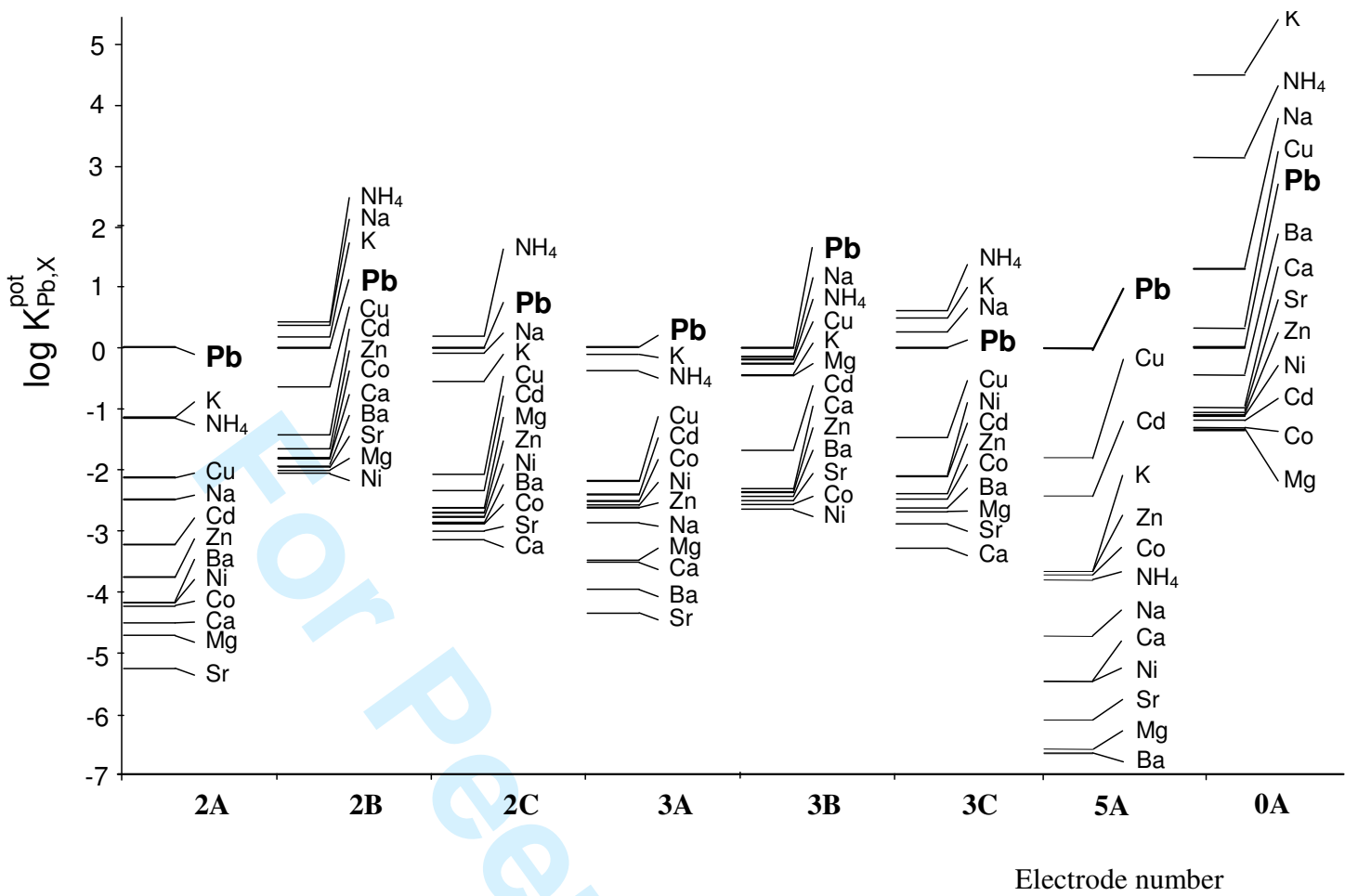

Figure 6 Selectivity coefficients $\log K_{P b, X}^{p o t}$ for membrane electrodes doped with compound $\mathbf{2 , 3}$ or $\mathbf{5}$ (plasticizer: A - o-NPOE, B - BBPA, C - DOP). 0 - "blank electrode".

\section{Graphical Abstract}

Pyrrole Azocrown Ethers. Synthesis, Complexation, Selective Lead Transport and IonSelective Membrane Electrode Studies

ELŻBIETA LUBOCH ${ }^{1}$, EWA WAGNER-WYSIECKA ${ }^{1}$, MARINA FAINERMAN-MELNIKOVA ${ }^{2}$, LEONARD F. LINDOY ${ }^{2}$, and JAN F. BIERNAT ${ }^{1}$

${ }^{1}$ Gdansk University of Technology, Department of Chemical Technology, Narutowicza 11-12, 80-952 Gdańsk, Poland; ${ }^{2}$ Centre for Heavy Metals Research, School of Chemistry, University of Sydney, NSW 2006, Australia

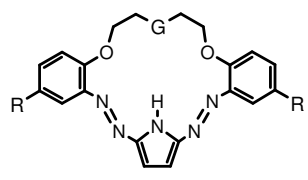

New 21-membered lipophilic crown ethers, each incorporating a pyrrole unit and two azo groups as macrocyclic ring components, have been synthesized. The complexation behavior of macrocycles has been investigated in acetonitrile. These ligand systems have been employed as ionophores in transport experiments and in solvent polymeric membrane electrodes. In each case selectivity for lead(II) was obtained. 



9 

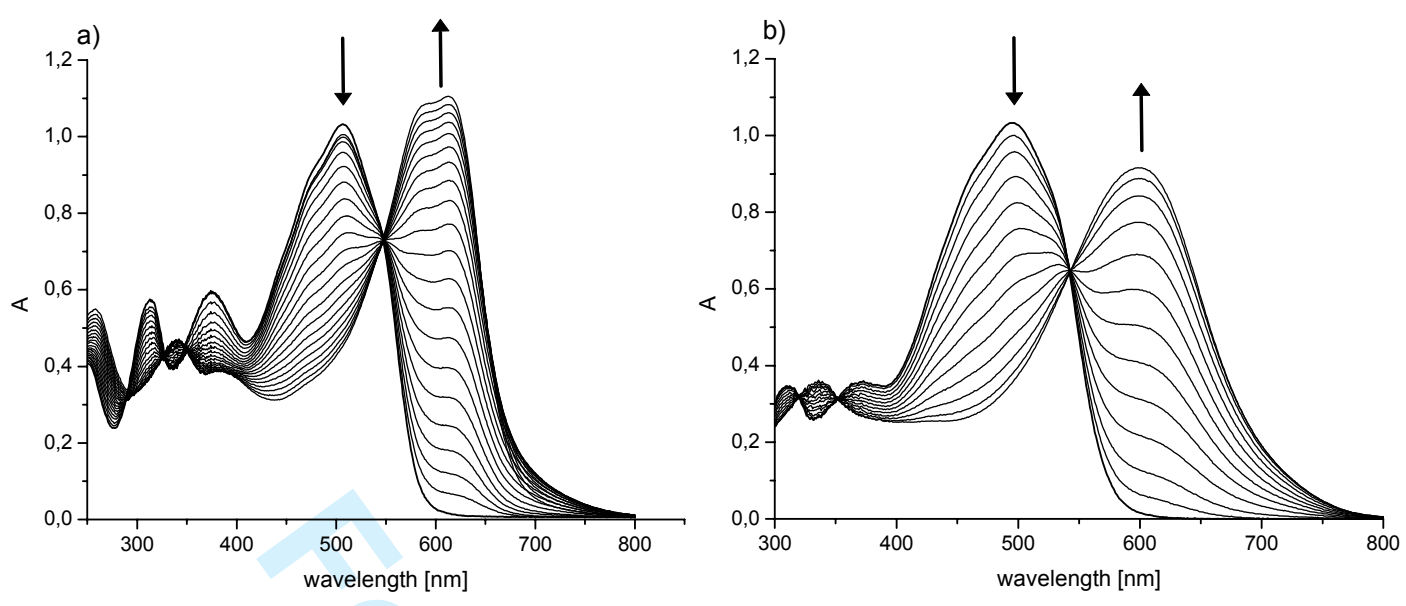

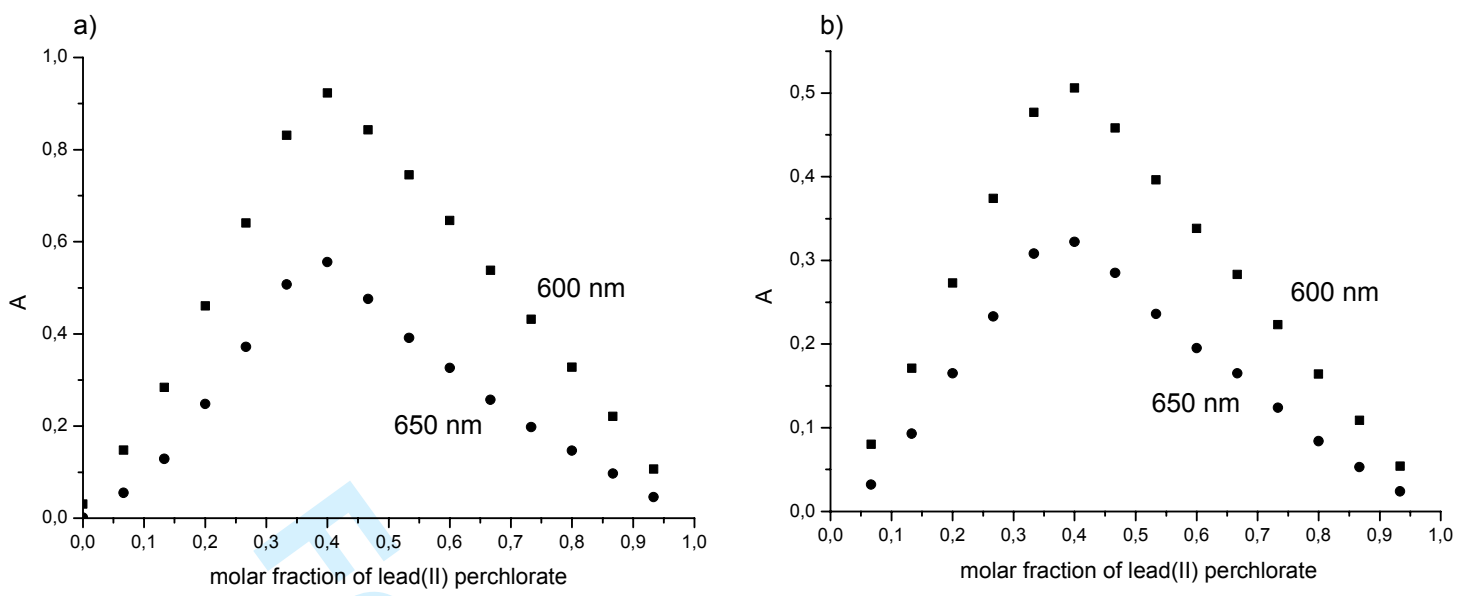


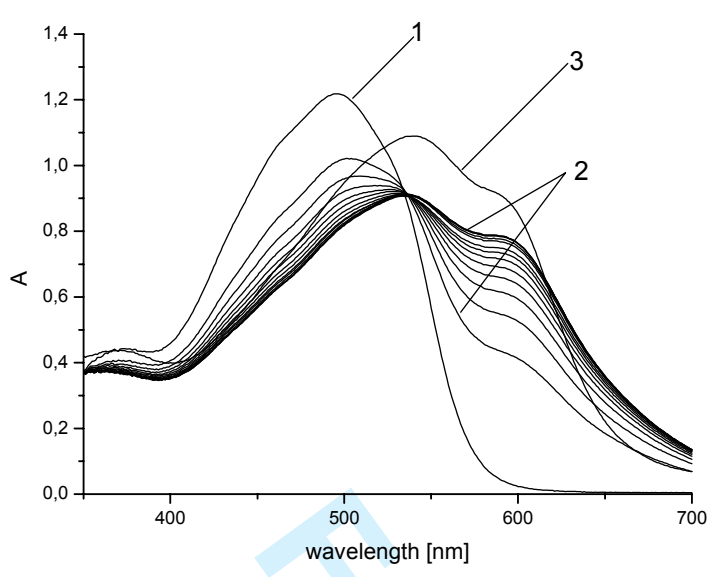

16 


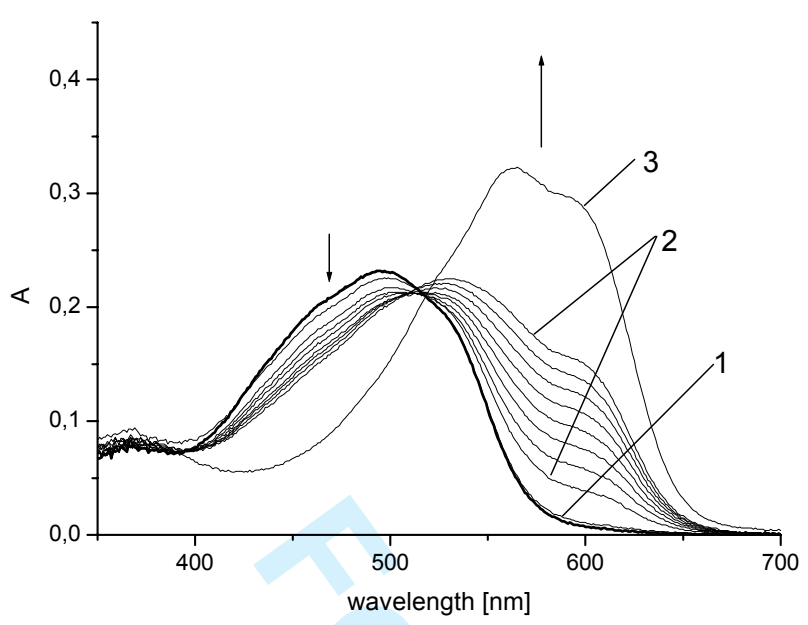

19 


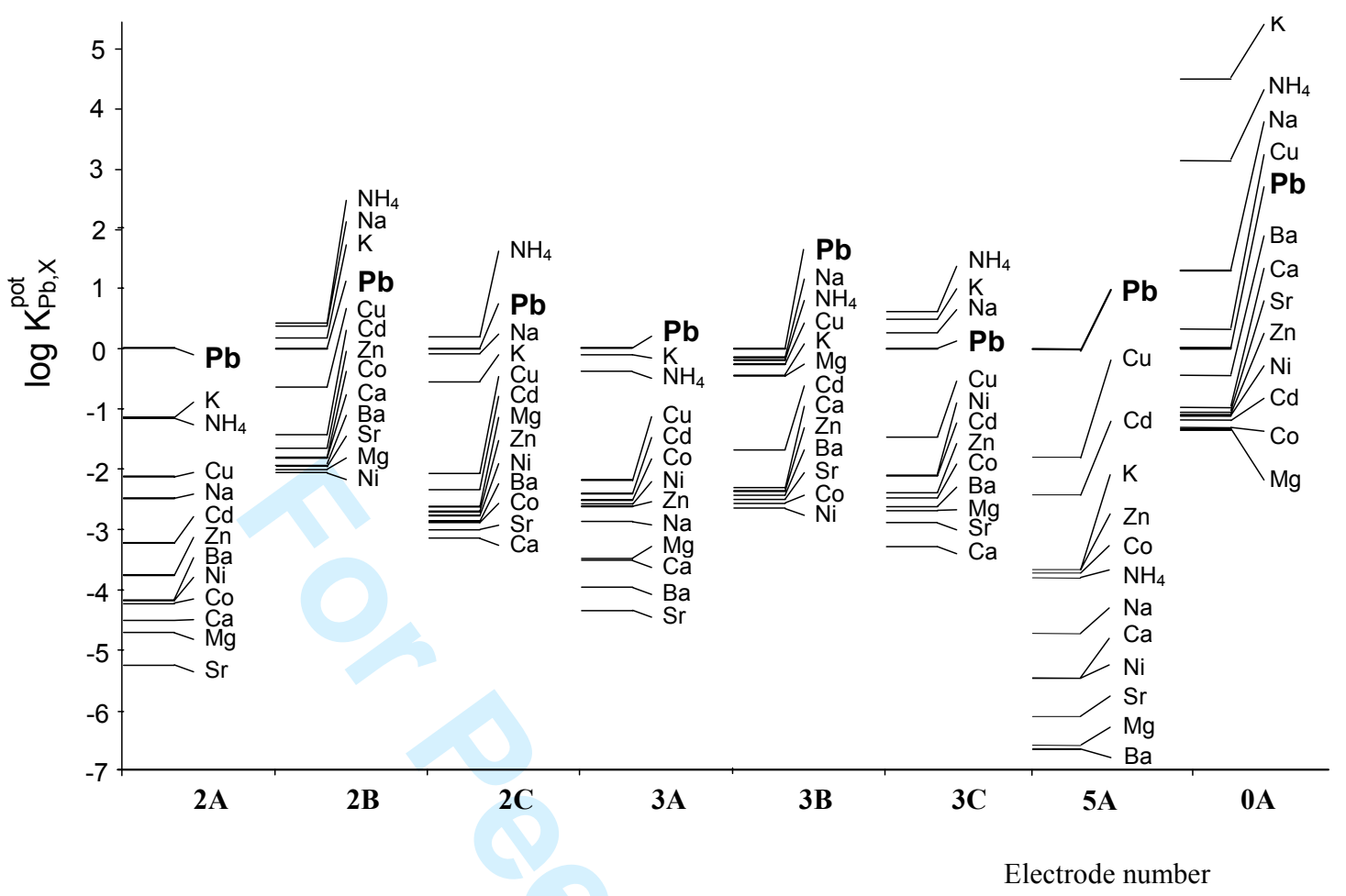




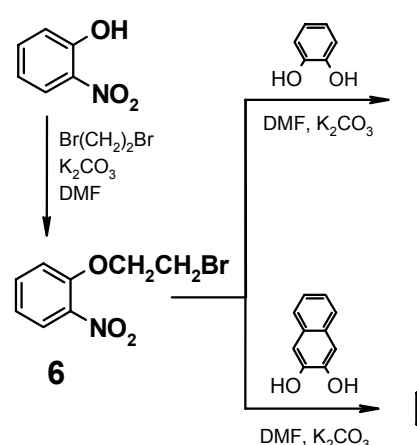<smiles>O=[N+]([O-])c1ccccc1OCCOc1ccccc1OCCOc1ccccc1OCCOc1cc2ccccc2cc1OCCOc1ccccc1[N+](=O)[O-]</smiles><smiles>Nc1ccccc1COc1ccc(N(N)c2ccccc2OCCOc2cc3ccccc3cc2OCCOc2ccccc2OCCOc2ccccc2N)cc1OCCOc1ccccc1N</smiles><smiles>COCOc1ccc(C(C)(C)C)cc1[N+](=O)[O-]</smiles>

8

10

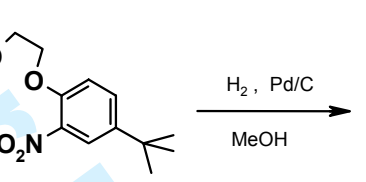

11

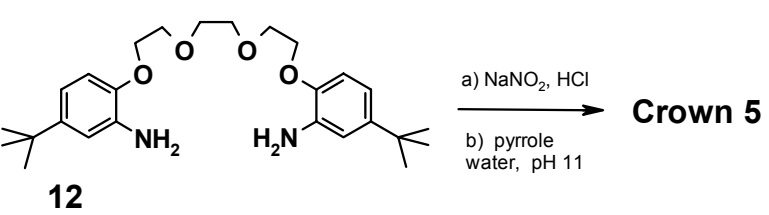

